\title{
Origin and Tectonic Framework of the Ngovayang Iron Massifs, South Cameroon
}

\author{
Ndong Bidzang Francois ${ }^{1,2, ~ *, ~ S o b d j o u ~ K e m t e u ~ C h r i s t e l ~}{ }^{1,2}$, Mero Yannah ${ }^{1}$, \\ Ntomba Martial Sylvestre ${ }^{1,2}$, Nzenti Jean Paul ${ }^{2}$, Mvondo Ondoa Joseph ${ }^{2}$ \\ ${ }^{1}$ Institut of Geological and Mining Research, Yaounde, Cameroon \\ ${ }^{2}$ Faculty of Sciences, University of Yaounde I, Yaounde, Cameroon
}

\section{Email address:}

fndongbidzang@gmail.com (N. B. Francois)

\section{To cite this article:}

Ndong Bidzang Francois, Sobdjou Kemteu Christel, Mero Yannah, Ntomba Martial Sylvestre, Nzenti Jean Paul, Mvondo Ondoa Joseph. Origin and Tectonic Framework of the Ngovayang Iron Massifs, South Cameroon. Science Research. Vol. 4, No. 1, 2016, pp. 11-20. doi: 10.11648/j.sr.20160401.13

\begin{abstract}
The Ngovayang massifs belong to the Paleoproterozoic Nyong unit complex located in the north western edge of the Congo Craton of southern Cameroon. It consists of granitoids and a banded series. The banded series presents the petrographic and geochemical characteristics of greenstone belts similar to those of Sao Francisco Craton in Brazil. Pervious works in this area involved geochemical (\% Fe), mineralogical (hematite/magnetite) and geophysical characterization of the formation ores. The sedimentary and tectonic events related to the ore emplacement are poorly understood and has an effect on the exploitation of these ores in Cameroon. The objective of this work is to generate new petrographic and geochemical data of the Ngovayang massifs, and to determine the origin and emplacement process that favored the accumulation of these ironbearing ferruginous quartzites in the study area. Polished thin sections were produced and observed using a scanning electron microscope at the Centre for Microscopy and Microanalysis, University of Western Australia CMM-UWA. Geochemical analysis of major and trace elements were carried out using XRF and ICP/MS in OMAC laboratory of Ireland. The results showed that the iron formation of the Ngovayang area composed of ferruginous and banded ferruginous quartzites series. Quartz, hematite and aluminosilicates occur as the main minerals associated with the ferruginous quartzite series. Geochemically, these ferruginous facies are very rich in Fe and Si but poor in other elements. Platy and massive type of mineralization were common with the hematites and are indicative of either metasomatic (or hydrothermal) origin and lateritic through meteoric water circulation. Three phase mineralization were identified from microscopic study: early Syn-sedimentary phase linked to the sedimentation of BIFs, a secondary tectonics phase and a tertiary phase related to weathering. The Ngovayang iron formations are characteristic of the lake superior-type.
\end{abstract}

Keywords: Ngovayang Massif, Lake Superior, Metasomatism, Ferruginous Quartzites, BIF

\section{Introduction}

The Precambrian basement of southern Cameroon experienced a thermotectonic evolution which favoured the emplacement of ferriferous formations commonly called Band Iron Formations (BIFs) and itabirites. BIFs are subcrustal formations which form the green stone belt [1]. The sedimentary and tectonic events related to BIFs emplacement favoured the accumulation of ferriferous mineralizations in these formations. These mineralization form a depression in the southern part of the country hosting huge deposits mainly located in Mbalam-Nababa (57.3\% Fe), Nkout (66\% Fe), Akom II (35\%Fe), Edea (32.1\% Fe), Ma'an
(29.7\%Fe), Ngoila (30\%Fe), Mewongo $(64 \% \mathrm{Fe})$, Salapoumbe, Messondo and Ngovayang (Fig. 1). Studies on iron formations in the Ngovayang massifs have been carried out by [2] with focus on the geochemistry of pyroxenite, amphibolites and their weathered products highlighting indices of Au-PGE group that are of economic value. On In the south eastern part of the region, [3] carried out mineralogical and geochemical study of the Nkout iron ore deposit. This work presented evidence of hematite, magnetite and martite mineralization. The hematite texture evolves from a martitic to a platy texture. The percentages by weight of iron oxide $\left(\mathrm{Fe}_{2} \mathrm{O}_{3}\right)$ are up to $92 \%$. The previous study also attributes an origin for this mineralization which is related to 
precipitation and deposition by the mixing of seawater and Precambrian hydrothermal fluids from the late Archean to early Proterozoic. This work presents the mining characteristics and is mainly based on three components; the search for magnetic rocks on the field using a magnetic pen; the search for iron-bearing minerals (hematite/magnetite) and the evaluation of iron contents $(\% \mathrm{Fe})$. However, the sedimentary and tectonic events related to their emplacement are not well known. This difficulty is observed from the evaluation of deposits and methods for the extraction and processing of iron ore in Cameroon. The Ngovayang area is a key area to carry out a geological survey in the north western edge of the Congo craton in southern Cameroon not only because it host the largest massifs, but also it forms a triple point between the Panafrican group of the Yaounde formations to the North, the Ntem complex formations in the South West and the Nyong complex formations in the South East. The objective of this article is to make use of new petrographic and geochemical data, provide new knowledge on the origin and the emplacement process that let to the accumulation of iron-bearing mineralizations in these formations through the study of ferruginous quartzites of the Ngovayang massifs.

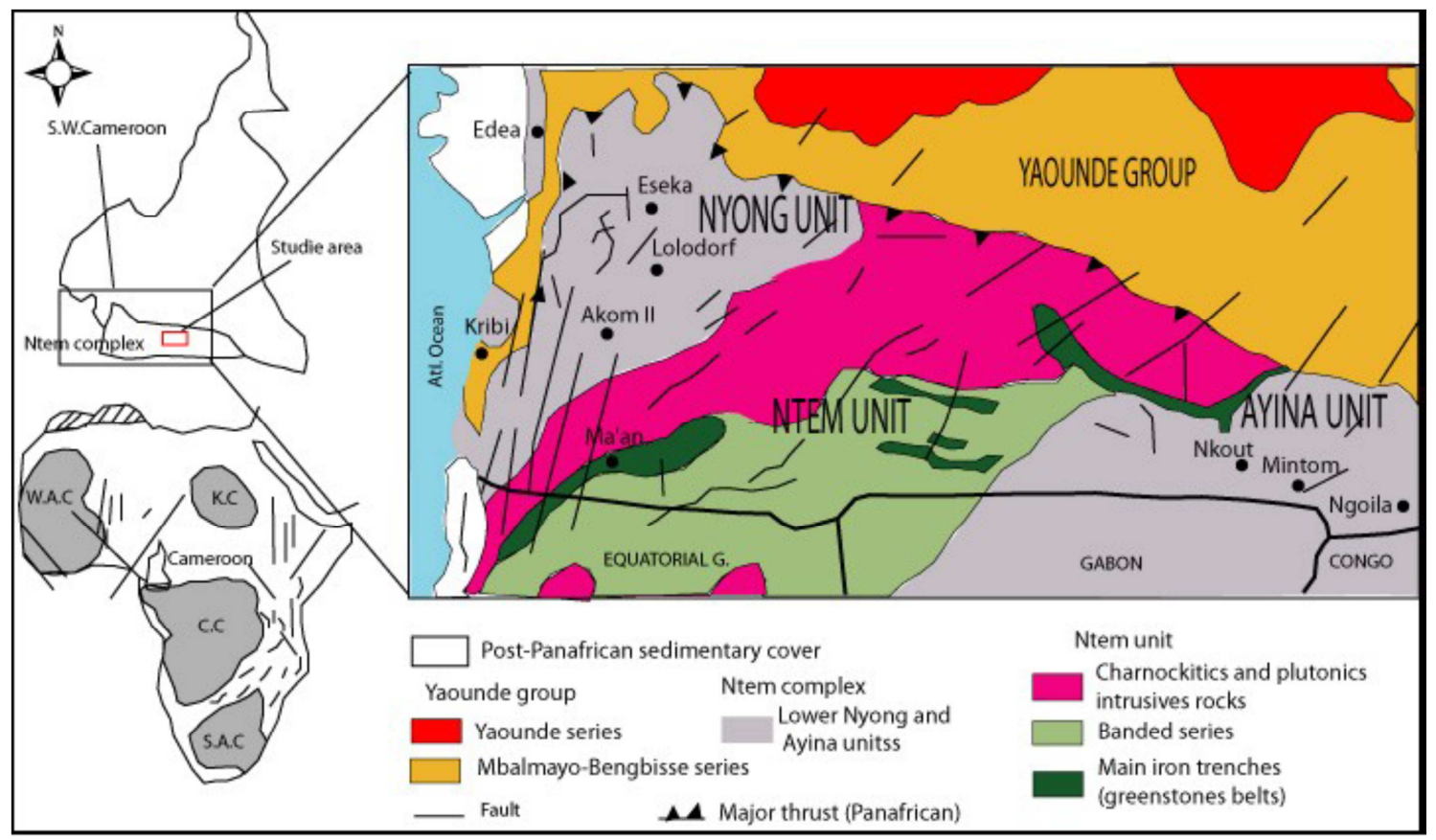

Figure 1. Geological map of south western Cameroon showing the main iron deposits.

The ferriferous depression of the Eburnian Ngovayang massifs belong to the tectonic and Paleoproterozoic Nyong unit. The Nyong unit is the northern part of the Ntem complex and constitute the pre-to-syntectonic granitoids and the banded series. The banded series has petrographical and chemical characteristics of the green stone belt facies of rocks [1] including basic and ferriferous or sterile quartzitic rocks [4]. In Lolodorf-Ngomezap rocks belonging to the green stone belt are characterized by an association of metabasic rocks (basic gneiss, pyroxenites and ferruginous quartzites) [2] during which amphibolites and quartzites suffered granulitic metamorphism with pyroxenes and garnets of the Ntem unit. The tectonic and metamorphic events that affected these rock formations show evidence of structural evolution which was more intense than in the Ntem unit during the Eburnian Orogeny with the influence of the Pan-African [5]. The Eburnian orogeny known to be responsible for the N-S structure and for the inclination on the Ntem and Nyong units in the south eastern part of the region [5]. The slight retromorphism in the green schist facies can be attributed to the Pan-African metamorphism [6].

\section{Materials and Methods}

Two sets of representative samples composed of 15 each were collected from the different quartzite facies (banded, massive and leucocratic) in the study area. One set was used for microscopic studies to produce polished thin sections at the Centre for Microscopy and Microanalysis, University of Western Australia CMM-UWA in Australia for petrographical, mineralogical and structural observations. Geochemical analyses were carried out using on the second set of 15 samples in the OMAC laboratory in Ireland. Major elements were analysed by X-ray fluorescence (XRF Phillips PW 1840) and trace elements by Inductively Coupled Plasma-Mass Spectrometry on a VG-Plasma Quad STE ICP mass spectrometer in the OMAC laboratory in Ireland of the ALS Geochemistry group. The samples were dissolved in a Teflon bomb under high pressure using a $1 / 1$ mixture of $\mathrm{HF}$ and $\mathrm{HClO}_{4}$ at $180^{\circ} \mathrm{C}$, which is then put in a $\mathrm{HNO}_{3}$ solution under standard internal/room conditions. After their dissolution in $\mathrm{HF}-\mathrm{HClO}_{4}$, the samples were introduced in a $\mathrm{HNO}_{3}, 6 \mathrm{NHCl}$ and $\mathrm{HF}$ mixture and then 
diluted. These solutions were measured 24 hours after their dilution to prevent absorption of HFSE on the sample bottles. The analytical uncertainties was about $1 \%$ for major elements, $5-10 \%$ for trace elements, $5 \%$ for REE with $>$ $10 \mathrm{ppm}$ and $10 \%$ for REE with $<10 \mathrm{ppm}$.

\section{Results and Discussion}

\subsection{Petrography}

The results from field observations showed that the study area composed of a variety of rocks made up of duricrusts and ferruginous laterities, basic gneiss and granitoids (TTG), metabasites (pyroxenites, amphibolites) and ferruginous quartzites. Magnetic pens were used to identify ferriferous rocks in the field. Despite the abundance presence of ferromagnesian minerals in the metabasites, their iron bearing percentage was quite low thereby making them less favourable for iron mineralization. For the purpose of this work, only the quartzitic formations have been retained for this study made up of three facies: banded ferruginous quartzites, massive ferruginous quartzites, and leucocratic quartzites (Fig. 2).

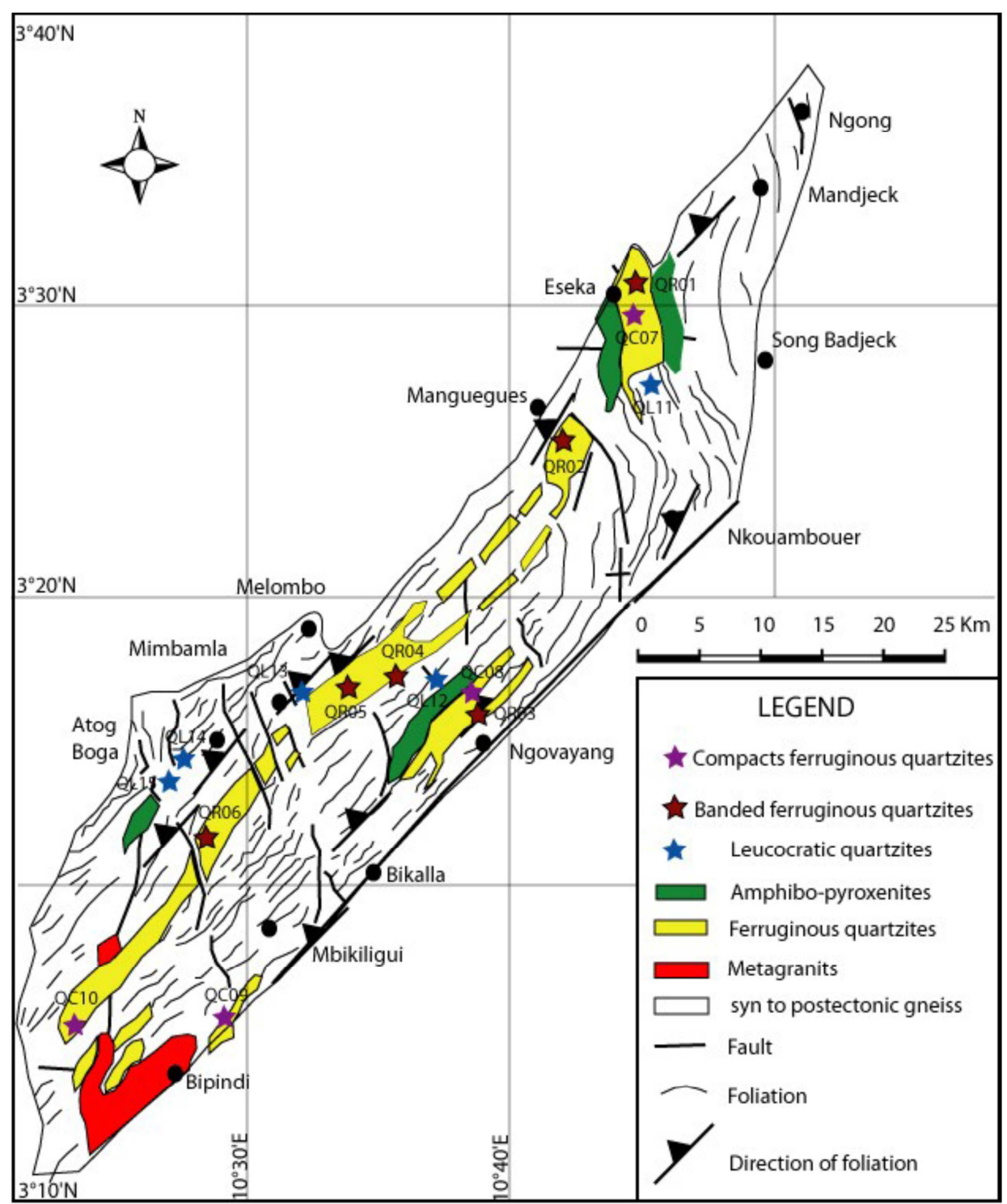

Figure 2. Study area showing the Ngovayang massifs and sample points.

\subsection{Banded Ferruginous Quartzites}

These banded rock facies occurs as piles of very thin, non-cohesive layers of hematite, which are loose and powdery in some portions (Fig. 3a, 3b). These layers were iron-rich but contain of silico-ferruginous sand with relatively low iron contents. Another distinctive aspect identified is the depth of occurrence that range between 25-
$45 \mathrm{~m}$ and up to $75 \mathrm{~m}$ at some locations. The mineralogy observed from the thin sections indicate the presence of quartz, iron oxides and alumino-silicates (stilpnomelane often transformed to kaolinite). Iron oxides occur in four successive facies which include: magnetites of varying sizes, small hematite conserved in chert bands forming micro-bandings (Fig. 3c, 3d), martite which occurs in 
magnetite indicating primary alteration and lastly secondary hematite which is a product from oxidation of primary hematite and precipitated in fissures (Fig. 3k, 31). These hematites appear grey to white under the microscope. They show tabular or plane crystals form with both large and small crystals sizes dispersed in quartz bands showing a red internal reflection (Fig. 3e, 3h). The small size crystals are less common compared to the large ones. However, the light bands of the banded quartzite facies are made up of mosaic quartz crystals with varying sizes. Two types of bands were distinguished: bands with large hexagonal crystals common through out the formation, bands with exclusively small hexagonal to euhedral quartz crystals that alternates with the large hexagonal crystal and thin hematite bands. This type of bands are mainly associated with stretched or boudinaged quartz veins. On the other hand, the hematite bands consist of $>90 \%$ hematite and accessory fine magnetite crystals commonly martitite and ilmenite.
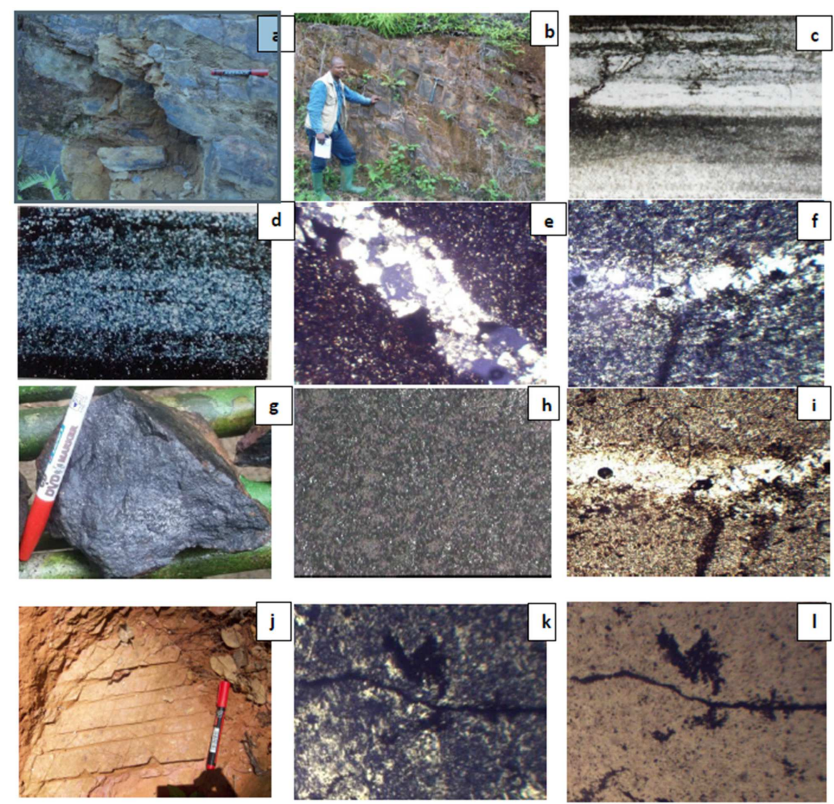

Figure 3. Photograph illustrating the appearance of quartzite of the Ngovayang massif. (a) plate type outcrop of ferruginous quartzite with a banded facies at Bipindi.(b) layered type outcrop of ferruginous quartzite with a banded facies at a road embankment in Manguegues. (c) microphotograph (NAPL, Gr10X) of the banded facies related to tectonics. (d) microphotograph (NAPL, Gr10X) of the banded facies. (e) microphotograph (NAPL, Gr 10X) showing the alteration of the hematite to martite and the silicification process. (f) microphotograph (APL Gr10X) showing the precipitation of hematite in tectonic fractures. (g) Photograph of massive ferruginous quartzite sample. (h) microphotograph showing the assemblage of quartz + hematite in a massive quartzite facies under reflected light. (i) microphotograph showing mineralization related to tectonic deformation (j) Photograph of a leucocratic quartzite sample $(k)$ microphotograph (NAPL, Gr10X) indicating the precipitation of hematite in tectonic fractures. (l) microphotograph (APL Gr10X) showing the precipitation of hematite in the tectonic fractures.

\subsection{Massive Ferruginous and Leucocratic Quartzites}

a) Massive Ferruginous

The massive quartzites occur as veins and in deformed clusters (Fig. 3g) that regularly show combined joints.
Mineralization is dispersed within the massive rock following well marked former benches and bedding planes (sedimentary relics), and are quite concordant with that of the enclosing gneiss. These veins and lenticular masses deeply rooted (several hundred meters below the present topographic surface). The de-silicification of this facies is almost complete. The massive facies generally occur as isotropic to sub-isotropic in the area, composed primarily of quartz and oxides (hematite in particular, rare fine magnetite crystals) in approximately equal proportions. The rocks exhibit fine texture which are less weathered as compared to other facies.

b) Leucocratic Quartzites

The leucocratic quartzite facies showed a characteristic light color indicative of the presence of non-ferromagnetic iron oxides (Fig. 3j). They occur often in association with the massive and banded ferruginous facies type. This can be explained that the leucocratic quartzites were formed by partial melting of granitoids rocks.

\subsection{Geochemistry}

\subsubsection{Major and Trace Elements}

Data on the composition of major, trace and rare earth elements of the different ferruginous quartzite facies is presented in table 1. The main geochemical characteristic of these formations is their iron-rich content. The $\mathrm{Fe}_{2} \mathrm{O}_{3}$ content ranges from $94.36-71.09 \%$ and $\mathrm{SiO}_{2}$ vary from $12.42-2.55 \%$ in the banded facies. In the massive facies, the $\mathrm{Fe}_{2} \mathrm{O}_{3}$ content ranges from $61.81-40.41 \%$ and $\mathrm{SiO}_{2}$ from 46.75-14.01\%. The leucocratic facies show $\mathrm{Fe}_{2} \mathrm{O}_{3}$ values ranging from $26.75-5.66 \%$ and $\mathrm{SiO}_{2} 87.76-49.77 \%$. The remaining major elements show very low concentration. Based on the $\mathrm{Fe}_{2} \mathrm{O}_{3}$ and $\mathrm{SiO}_{2}$ concentrations indicated, it can be explained that the rocks of this have undergone successive remobilization during their formation leading to iron enrichment. According to [7], the measured iron content in the area is $43 \%$ as oppose to $66 \%$ recorded in this work (table 1 ). In a similar manner, $\mathrm{Al}_{2} \mathrm{O}_{3}$ showed an increased from $0.79-15.46 \%$. Based on the petrographycal and geochemical data, a number of observations were identified to characterize the ferruginous rocks of this area in comparison with the reference data (BIFs): (i) $\mathrm{Fe}$ and $\mathrm{Si}$ occur as the main elements of the Ngovayang massifs with a characteristic negative correlation (Fig. 4), (ii) with the exception of iron that shows a slight variation in concentration, the remaining elements show concentrations below the Clarke standard [8], (iii) no clear correlation exist between $\mathrm{Fe}_{2} \mathrm{O}_{3}$ and other major elements. The variation of the other major elements contents is random with respect to iron (Fig. 4 and 5). Sample QL11 recorded the highest silica content $(87.76 \%)$ but very poor in iron $(5.66 \%)$ though with a high $\mathrm{Ca}$ content which could probably be related to the presence of a silica-carbonate phase. The chemical composition of sample QL11 excludes it from the mineralized ferruginous quartzite (table 1). 
Table 1. Major and trace element concentration for Ngovayang massif quartzites.

\begin{tabular}{|c|c|c|c|c|c|c|c|c|c|c|c|c|c|c|c|}
\hline \multirow[b]{2}{*}{ Sample } & \multicolumn{6}{|c|}{ Banded Ferruginous (QR) } & \multicolumn{4}{|c|}{ Massive Ferruginous (QC) } & \multicolumn{5}{|c|}{ Leucocratic Quartzite (QL) } \\
\hline & QR01 & QR02 & QR03 & QR04 & QR05 & QR06 & QC07 & QC08 & QC09 & QC10 & QL11 & QL12 & QL13 & QL14 & QL15 \\
\hline $\mathrm{SiO}_{2}$ & 2.55 & 2.57 & 8.52 & 12.42 & 9.67 & 8.35 & 21.28 & 46.75 & 14.01 & 18.94 & 87.76 & 69.87 & 70.20 & 49.77 & 73.58 \\
\hline $\mathrm{Al}_{2} \mathrm{O}_{3}$ & 1.43 & 1.44 & 2.02 & 2.98 & 2.44 & 5.94 & 5.67 & 2.86 & 11.75 & 15.46 & 1.96 & 0.80 & 0.79 & 12.34 & 9.69 \\
\hline $\mathrm{Fe}_{2} \mathrm{O}_{3}$ & 94.36 & 93.86 & 76.70 & 71.09 & 72.86 & 73.54 & 61.27 & 40.41 & 61.81 & 51.46 & 5.66 & 26.72 & 26.75 & 13.41 & 6.75 \\
\hline $\mathrm{MnO}$ & 0.02 & 0.02 & 0.10 & 0.49 & 2.31 & 0.04 & $<0.01$ & 0.58 & 0.01 & 0.01 & 0.02 & 0.02 & 0.02 & 0.19 & 0.02 \\
\hline $\mathrm{MgO}$ & 0.11 & 0.11 & 0.17 & 0.31 & 0.48 & 0.03 & 0.37 & 0.18 & 0.02 & 0.02 & 0.25 & 0.03 & 0.03 & 6.20 & 1.44 \\
\hline $\mathrm{CaO}$ & $<0.01$ & 0.01 & 0.01 & 0.02 & 0.03 & $<0.01$ & 0.01 & 0.03 & $<0.01$ & $<0.01$ & 0.04 & 0.02 & 0.02 & 9.23 & 0.07 \\
\hline $\mathrm{Na}_{2} \mathrm{O}$ & $<0.05$ & $<0.05$ & $<0.05$ & $<0.05$ & $<0.05$ & $<0.05$ & $<0.05$ & $<0.05$ & $<0.05$ & $<0.05$ & $<0.05$ & $<0.05$ & $<0.05$ & 2.53 & $<0.05$ \\
\hline $\mathrm{K}_{2} \mathrm{O}$ & $<0.01$ & $<0.01$ & 0.40 & 0.61 & 0.77 & 0.16 & 1.21 & 1.25 & 0.05 & 0.03 & 0.64 & 0.07 & 0.07 & 1.19 & 3.80 \\
\hline $\mathrm{Cr}_{2} \mathrm{O}_{3}$ & $<0.01$ & $<0.01$ & $<0.01$ & $<0.01$ & $<0.01$ & $<0.01$ & $<0.01$ & $<0.01$ & 0.04 & 0.08 & 0.05 & 0.03 & 0.03 & 0.01 & 0.04 \\
\hline $\mathrm{P}_{2} \mathrm{O}_{5}$ & 0.016 & 0.016 & 0.176 & 0.336 & 0.575 & 0.582 & 0.448 & 0.399 & 0.166 & 0.145 & 0.044 & 0.050 & 0.050 & 0.160 & 0.075 \\
\hline $\mathrm{TiO}_{2}$ & 0.14 & 0.14 & 0.07 & 0.12 & 0.10 & 0.96 & 0.23 & 0.13 & 0.75 & 1.40 & 0.08 & 0.03 & 0.04 & 1.84 & 0.41 \\
\hline LOI $1000^{\circ}$ & 2.76 & 2.74 & 11.63 & 10.54 & 10.74 & 9.51 & 7.93 & 6.47 & 9.47 & 10.04 & 1.52 & 0.90 & 0.78 & 1.54 & 3.36 \\
\hline $\mathrm{Fe}$ & 66.00 & 65.65 & 53.65 & 49.72 & 50.96 & 51.44 & 42.85 & 28.26 & 43.23 & 35.99 & 3.96 & 18.69 & 18.71 & 9.38 & 4.72 \\
\hline $\mathrm{Ba}(\mathrm{ppm})$ & 11 & 33 & 10 & 22 & 19 & 9 & 20 & 11 & $<2$ & $<2$ & & & & & \\
\hline Co & 6 & 8 & 17 & 6 & 10 & 16 & $<2$ & 14 & 13 & 13 & & & & & \\
\hline $\mathrm{Cr}$ & 40 & 13 & 13 & 9 & 7 & 19 & 18 & 28 & 46 & 7 & & & & & \\
\hline $\mathrm{Cu}$ & 16 & 16 & 17 & 13 & 8 & 16 & 7 & 7 & 15 & 13 & & & & & \\
\hline $\mathrm{Ga}$ & $<2$ & 26 & 21 & 29 & $<2$ & 23 & 24 & 26 & 18 & 26 & & & & & \\
\hline $\mathrm{Ni}$ & $<2$ & 21 & 26 & 22 & 24 & 14 & $<2$ & 13 & 20 & 24 & & & & & \\
\hline $\mathrm{Sr}$ & 26 & 7 & 34 & 23 & 25 & 23 & 21 & 32 & 20 & 8 & & & & & \\
\hline $\mathrm{V}$ & 16 & 19 & 52 & 19 & 29 & 42 & 26 & 41 & 21 & 17 & & & & & \\
\hline Y & 9 & 41 & 55 & 24 & 34 & 15 & 28 & $<2$ & 28 & 10 & & & & & \\
\hline $\mathrm{Zn}$ & $<2$ & $<2$ & $<2$ & $<2$ & $<2$ & $<2$ & $<2$ & $<2$ & $<2$ & $<2$ & & & & & \\
\hline $\mathrm{Zr}$ & $<2$ & $<2$ & $<2$ & $<2$ & $<2$ & $<2$ & $<2$ & $<2$ & $<2$ & $<2$ & & & & & \\
\hline $\mathrm{La}$ & $12 . .70$ & 15.63 & 12.64 & 4.34 & 13.41 & 8.96 & 13.81 & 13.29 & 13.30 & 12.05 & & & & & \\
\hline $\mathrm{Ce}$ & 41.40 & 10.75 & 11.15 & 8.23 & 15.97 & 16.95 & 16.98 & 16.39 & 24.80 & 38.00 & & & & & \\
\hline $\mathrm{Nd}$ & 16.00 & 14.64 & 14.72 & 3.23 & 24.60 & 6.74 & 28.80 & 26.20 & 10.05 & 16.35 & & & & & \\
\hline $\mathrm{Sm}$ & 2.60 & 7.20 & 6.86 & 0.61 & 4.10 & 4.41 & 4.30 & 6.19 & 3.10 & 0.87 & & & & & \\
\hline $\mathrm{Eu}$ & 1.34 & 1.33 & 0.17 & 0.15 & 0.85 & 0.26 & 0.94 & 0.80 & 0.42 & 0.78 & & & & & \\
\hline Gd & 1.19 & 0.72 & 4.52 & 3.55 & 2.41 & 0.69 & 2.96 & 2.95 & 2.55 & 2.65 & & & & & \\
\hline Dy & 0.58 & 0.68 & 0.36 & 1.47 & 0.81 & 2.58 & 0.91 & 1.33 & 0.62 & 1.93 & & & & & \\
\hline $\mathrm{Er}$ & 0.94 & 0.41 & 0.51 & 0.76 & 0.34 & 1.2 & 0.38 & 0.63 & 0.27 & 1.03 & & & & & \\
\hline $\mathrm{Yb}$ & 0.84 & 0.32 & 0.45 & 0.84 & 0.28 & 0.21 & 0.22 & 0.52 & 0.21 & 0.83 & & & & & \\
\hline
\end{tabular}

\subsubsection{Rare Earth Elements (REE)}

The normalization of these REE has been made with respect to North American Shale Composite (NASC, [9]). The resulting spectra of these REE ferruginous quartzites are represented in Fig 6. Except for sample QC7 with a particular spectrum showing a different fractionation from the other samples with a LREE enrichment and depletion in HREE, the other samples show virtually the same appearance with a marked positive Eu anomaly.

\subsection{Origin and Tectonic Framework}

The results indicate a possible three mineralization phases in the study area. It is indicated that for each phase, the initial concentration of iron has undergone independent evolutions during which the sedimentation and participates of iron followed a series of transformations. These transformations locally increase the initial concentration of iron thereby resulting to an economic deposit. The first mineralization phase is syn-sedimentary which is defined by banding or sedimentary alternation common with all varieties of BIF $_{S}$ in the Ntem complex and reflects the phenomenon of initial iron concentration (Fig. 3d). However, the centimetric banding characteristic of the Ngovayang massifs which is quite rare in other parts of the Ntem complex [3] can be related to the process of liquid segregation which enabled iron to migrate from the poor band to rich band and accentuating the iron content contrast between the two types of band. The phenomenon where by there is no modification of the average grade of the rock is common with diagenetic processes [10]. The second phase is related to tectonic processes. This phenomenon was clearly observed from the thin sections under the microscopic. Based on the petrography, the banded facies show centimetric banding composed of hematite and quartz reconcentration displaying two successive fold phases $\left(\mathrm{F}_{1}\right.$ and $\left.\mathrm{F}_{2}\right)$. During this process of folding, the hematite flows from the flanks to the hinges. The reconcentration phenomenon is consider the least important in terms of hematite reconcentration in the study area and can have an indirect effect which could result to subsequent reconcentrations. The mineralization is induced by brittle tectonic movement whereby hematite precipitates into cracks and joints (Fig. 3c, 31). 

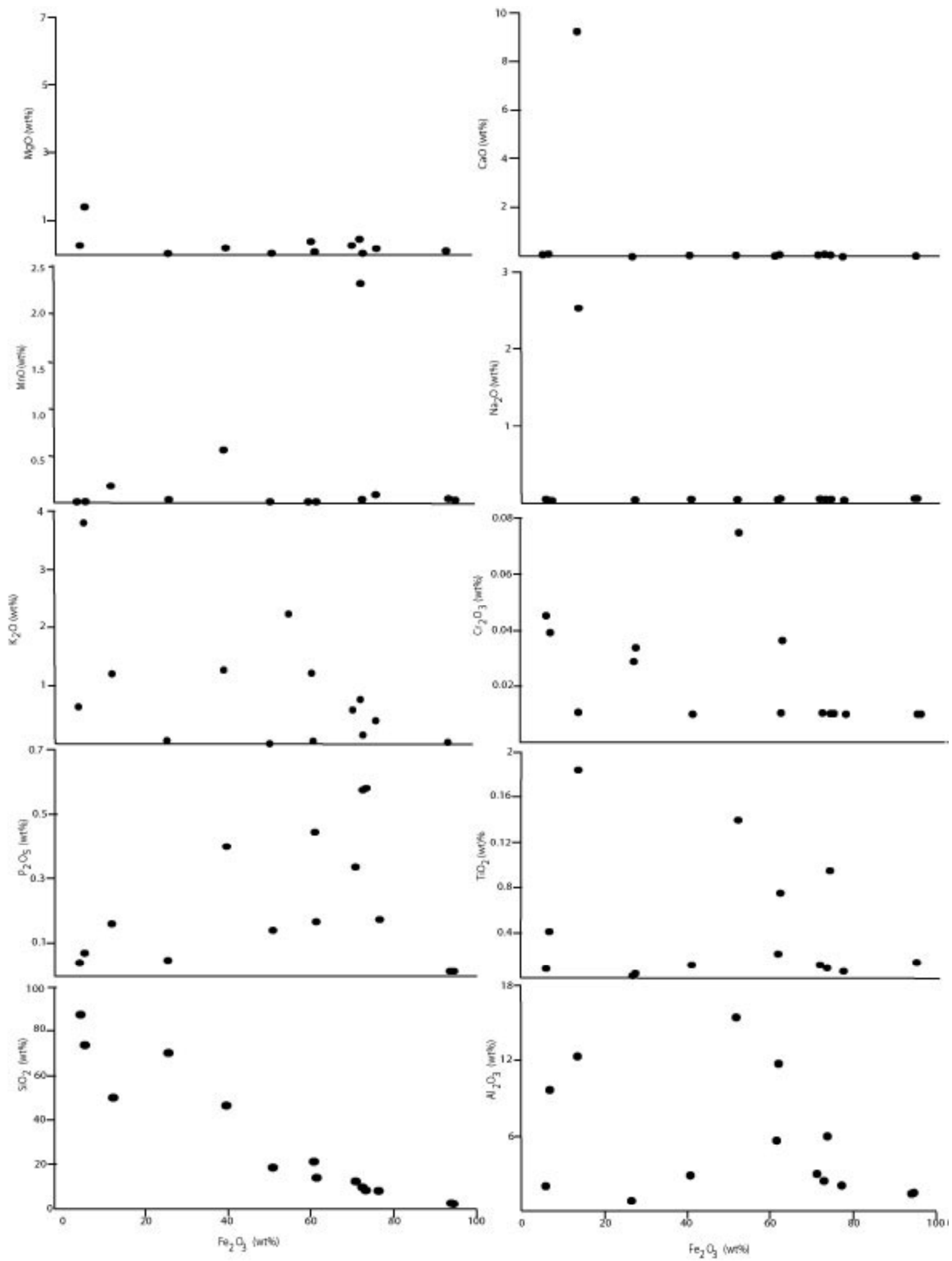

Figure 4. Variation of major elements as a function of $\mathrm{Fe}_{2} \mathrm{O}_{3}$. 

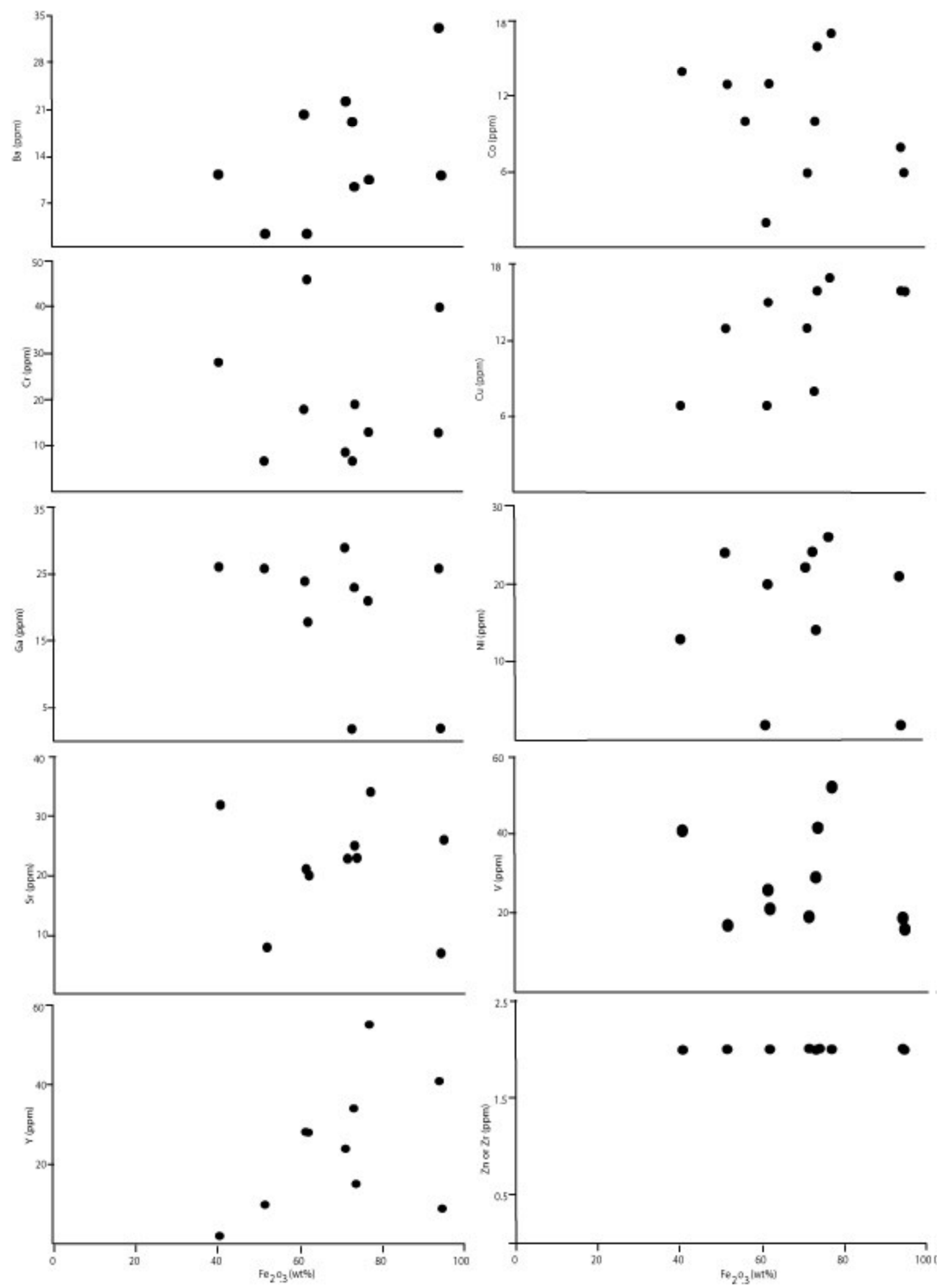

Figure 5. Variation of trace elements as a function of $\mathrm{Fe}_{2} \mathrm{O}_{3}$. 


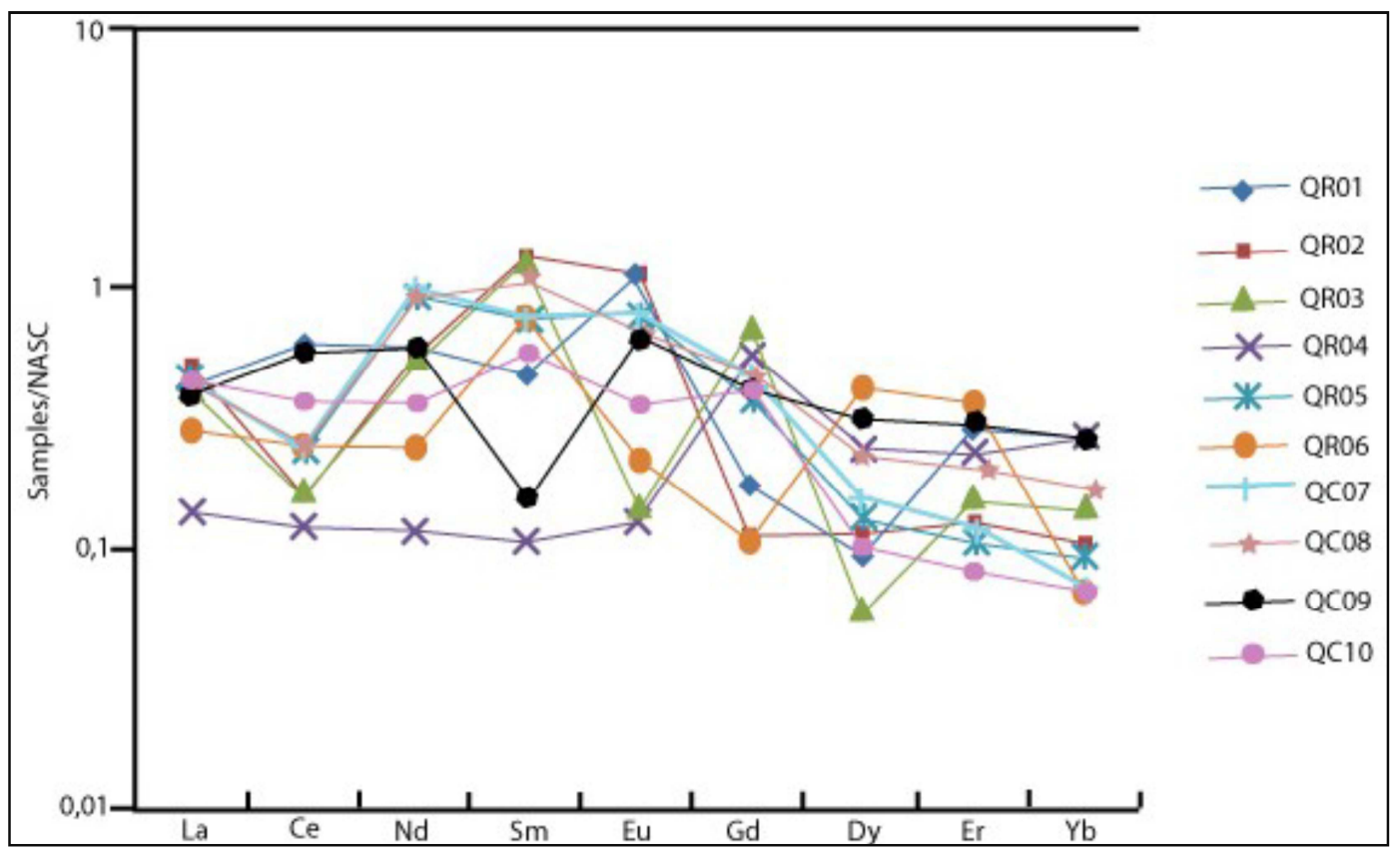

Figure 6. North American Shale Composite normalized REE patterns (adopted from Gromet et al., 1984).

The different types of deformations mentioned above increase the role played by solutions in the dissolution of quartz leading to an enrichment of hematite in the parent rock. This phenomenon is very conspicuous in the observed ore samples. These samples are rich in voids resulting from the dissolution of quartz minerals (Fig. 3k). Natural hematite concentrations are geological phenomenon with regional character closely found in quartzo-ferruginous formations of the northern edge of the Congo craton [11,3]. These quartzoferruginous formations lithologically correspond to rocks formed with millimetric alternations of band, generally of pure silica and a mixture of silica and hematite. These bands give the rock its characteristic macroscopic appearance which is a typical aspect of BIFs. These rocks are very similar to BIFs that host the Brazilian iron ore deposits [12]. This similarity can be explained by the same formations found in the Nyong unit (Congo Craton) and the Sao Francisco formations in Brazil, related to the collision of these two cratonic blocks during Eburnean orogeny [6, 1314]. Most hematite concentrations have a number of common geological features that enabled them to be classified into two major types: banded type and the massive type deposits. According [15], two main hypotheses regarding the origin of the mineralization have been suggested which includes the metasomatic and lateritic origins.

The metasomatic origin involves hydrothermal replacement of quartz by hematite which probably occurred during the last tectonic phase and the metamorphism of the ferriferous formations [16, 17]. It could be the result of hydrothermal fluids related to the emplacement of eruptive massifs/landforms [18]. The metasomatic hypothesis seems much unlikely simply because the eruptive phenomena are rare or non-existent in this area. The location of anomalies is closely related to the highly deformed areas than in the rest of massifs [19]. It is presumed that intense folding of iron formation is accompanied by an increased temperature either linked to hydrothermal fluids or to dynamic metamorphism $[20,21]$. This increase in temperature is proportional to subsurface depth which occurs in two stages: (i) the initial stage with a temperature of about $150^{\circ} \mathrm{C}$ at which silica is the only mineral that is driven towards the surface to form banded quartzites. The banded quartzites get enriched simply by desilification of the ore into layers. (ii) Secondary stage occurs at a greater depth of $450^{\circ} \mathrm{C}$ during which iron oxides mobilized with an upward movement. The solutions first exploits faults and joints and completely occupy the inter layer spaces of the hematite ore. At this point, the original rock structure is still intact but at greater depth subsequent tectonic stresses occur and the layered structure of the ore is destroyed to give a massive ore [15]. The hypothesis of a lateritic circulation by meteoric waters assumes that the mineralization vector would be meteoric water containing humic acids dissolving silica and leaving the iron in situ [22, 23]. The de-silicification seems to have occured in several phases [11]. However, the fact that the rich ore is still recognized at several hundred meters depth [11], while meteoric weathering hardly seems to exceed one hundred meters depth indicates the possibility of multiple agents of iron concentration. If the metasomatic theory is taken into account, age should be the end of the last tectonic phase, thus largely Precambrian [21]. On the contrary, if the lateritic theory is being considered, the age of the mineralization is recent and should be Tertiary [24]. In effect, several facts makes it possible that the mineralization could be partly Precambrian: (i) rocky pebbles of ores were found in the Infracambrian basal conglomerates of the Campo basin [25], (ii) the strict localization of mineralization with tectonic traps. Other facts on the contrary suggest that the mineralization is much more recent [22]. The first argument could be that desilicification occurs in countries with a 
tropical climate but such climate did not exist during the Precambrian. Secondly, massive hematite mineralization (Nkout, Mewongo, Messondo) are linked to intensely deformed zones and at great depths [11] suggesting the possibility of a probable role of hydrothermal fluids through faults, which was followed by a metasomatic replacement of silica by iron. Lastly, the hematite mineralizations occur at shallower depths where surface weathering is active. Fractures or joints between ferruginous quartzites served as traps promoting the circulation of water and thus the dissolution of silica and the concentration of hematite.

Genetic models for BIF type deposits have been and remain a subject of debate and controversy. The hypotheses of their emplacement are quite varied including sedimentary, volcano-sedimentary, volcanic and even cosmic. The first two (sedimentary and volcano-sedimentary) are the most adopted [26]. Nevertheless, the fact that the majority of BIFs are not associated with volcanic rocks, gives more credit to the hypothesis of a sedimentary origin. Furthermore, the source of the chemical elements is still widely debated with two main hypotheses considered valid: (i) a continental origin from the alteration of a continental crust, (ii) a hydrothermal origin (mantle for iron) involving the deposition of Fe and Si following a mixing of hydrothermal fluids rich in iron and silica with surface water [27-28]. On the other hand, the huge precipitation of $\mathrm{Fe}^{3+}$ requires significant amount of oxygen. Two processes are proposed as the basis for the release of oxygen in this environment: (i) photodissociation of the water vapour by ultra violet radiation [28-29] that involves bacteria activity. It would have required about 4 Billion years to deposit the BIFs of the Hamersley Basin in Australia while their emplacement were found to have taken only 2 million years [30-31]. Therefore, the photodissociation of the water alone cannot explain the production of such amounts of oxygen required. (ii) According to [28-32] photosynthesis seems to be the main process of oxygen release. Finally, seasonal organic activity has been invoked to explain the cyclic nature of iron-silica deposits in BIFs. It seems that during historic time, the hot and humid climatic promoted an increase in the development of organisms (high photosynthesis) and subsequently the oxygenation of the atmosphere that resulted to the precipitate of $\mathrm{Fe}^{3}$. Contrary to that, cold periods caused a decrease in organic activity and consequently silica fixing microorganisms were most active.

\section{Conclusions}

The Ntem group from a lithological point of view is characterized by the presence of an old basement which consists of gneisses and granitoids of TTG type, as well as greenstone belts with much recent banded iron formation (BIF). The Ngovayang massifs are characterized by their ferriferous nature. The iron formations extend for over a hundred kilometers along the massifs. The ferriferous quartzites shows a very simple mineralogy characterized by quartz, hematite and chlorite with low proportions of martite, magnetite and ilmenite. However, this simple mineralogy is explained geochemically by the extreme impoverishment in all chemical elements except for iron and silica. These two elements were negatively correlated thereby indicating a geochemical character and a probable leaching by meteoric water, leading to the formation of the ore body (hematite). This study enabled the identification of three main mineralization phases: the early syn-sedimentary related to BIFs sedimentation, a second and most important phase associated with tectonics, and the last phase associated with weathering. The hematite and rock type mineralization occur in this area. The origin of these mineralizations were related to two main hypotheses including metasomatic (or hydrothermal) and lateritic (circulating meteoric waters) origins.

\section{Acknowledgements}

The authors wish to thank the editor and reviewers for the constructive comments they provided to help improve the quality of this paper.

\section{References}

[1] Nsifa, N. E., Tchameni, R., Nédélec, A., Siqueira, R., Pouclet, A., Bascou, J., 2013. Structure and petrology of Pan-African nepheline syenites from the South West Cameroon; Implications for their emplacement mode, petrogenesis and geodynamic significance. Journal of African Earth Sciences $87,44-58$.

[2] Ebah, A. S. A., Ndjigui, P. D., Beyann, A. A., Teutsong, T., Bilong, P., 2012. Geochemistry of pyroxénites, amphibolites and their weathered products in the Nyong unit, SW Cameroon (NW border of Congo craton): implication for AuPGE exploration. Journal of Geochemical exploration Vol. 114-Mars 1.

[3] Nsoh, E. F., Agbor, A. K., Etame, J., Suh, E. C., 2014. Oretextures and geochemistry of the Nkout iron deposit, South East Cameroon. Sciences, Technologies et Développement, Volume 15, pp 43-52.

[4] Vicat, J. P., 1998. Bilan des connaissances acquises sur les séries de Dja (Cameroun), Nola (Centrafrique) et SembeOuesso (Congo. In: Vicat J. P. et Bilong P. éd., Géosciences au Cameroun, Collect. GEOCAM, 1/1998, Press. Univ. Yaoundé, pp. 369-383.

[5] Nédéleck, A., Nsifa, E. N., Martin, H., 1990. Major and trace element geochemistry of The Archean Ntem plutonic complex (South Cameroun): Petrogenesis and crustal evolution Precambrian Res., 35-50.

[6] Toteu, S. M., Van Schmus, W. R. Penaye, J. and Nyobe, J. B., 1994. U-pb and Sm-Nd evidence for Eburnian and Pan-african high-grade metamorphism in cratonic rocks of Southern Cameroon. Prec. Res, 67, 321-347.

[7] Minyem, D. and Nédélec A., 1990. Origin and evolution of the Eseka gneisses (Cameroon). Archean TTG reworked in the panafrican mobile belt. Inc: 15th, coll. Geol. Afr., Nancy, Publ. Occas. CIFEG, 2. Etude récente sur la géologie de l'Afrique 21-24. 
[8] Taylor, S. R., 1964: Abundance of chemical elements in the continental crust: a new table. Geochim. Cosmochim. Acta 28(8): 1273-85.

[9] Gromet, L. P., Dymek, R. F., Haskin, L. A., Korotev, R. L., 1984. The "North American Shale Composite", its compilation, major and trace element characteristics. Geochim. Cosmochim. Acta, 48, 2469-2482.

[10] Bronner, G., Chauvel, J. J., Triboulet, C., 1990a. Geochemistry and knowledge of banded iron formations: The Western African Shield, an example. in Ancient banded iron formations (Regional presentations), Theophrastus Publ., Athens, Greece, p. 135156.

[11] Ngoumou, P. C., Ndougsa, M. T., Assembe, S. P., Kofane, T. C., 2014. Evidence of iron mineralization channels in the Messondo Area (Centre - Cameroon) using Geoelectrical (DC\&IP) methods: a case study. Int. Jour. of Geosciences, 5, 346-361.

[12] Cesar, A. C., Varajao., Ary, B., Erick, R., Ramanaidou., Robert, J. G., 2002. Microporosity of BIF hosted massive hematite ore, Iron Quadrangle, Brazil. Anais da Academia Brasileira de Ciências 74(1): 113-126.

[13] Lerouge, C., Cocherie, A., Toteu, S. F., Milesi, J. P., Penaye, J., Tchameni, R., Nsifa, N. E., Fanning, C. M., 2006. SHRIMP $\mathrm{U}-\mathrm{Pb}$ zircon dating for the Nyong Series, South West Cameroon. J. Afric. Earth Sci. 44 (4-5), 413-427.

[14] Shang, C. K., Wolfgang, S., Muharrem, S., Funken, C., Mvondo Ondoa, J., 2004b. Zircon $\mathrm{Pb}-\mathrm{Pb}$ and $\mathrm{U}-\mathrm{Pb}$ systematics of TTG rocks in the Congo Craton: constraints on crust formation, magmatism, and Pan-African lead loss. Bull. Geos. 79 (4), 205-219.

[15] Thibaut, P. M., Ralay, F., 2001. Inventaire des minières de fer de la Haute-Marne. Etat d'avancement des travaux réalisés en 2001. Rapport BRGM/RP- 51372-FR

[16] Dorr, J. V. N., Barbosa, A. L. M., 1963. Geology and ore deposits of the Itabira district. US Geol Surv Prof Pap 109, p. 341-C.

[17] Dorr, J. V. N., 1965. Nature and origin of the high-grade hematite ores of Minas Gerais, Brazil. Econ Geol 60: 1-46.

[18] Guild, P. W., 1953. Iron deposits of the Congonhas District, Minas Gerais. Econ Geol 48: 639-676.

[19] Bidzang, F. N., Messi, E. J. O., Ntomba, S. M., Akam, M. J., Ondoa, M. J., 2015. Contribution of satellite lineaments to search for gold showings of Eburnean massive Ngovayang south Cameroon (Craton of Congo). International Journal of Innovation and Applied Studies. 13(2), 368-376.
[20] Harder, E. C., Chamberlin, R. T.; 1915. The geology of central Minas Gerais, Brazil. Jour Geol Part I 23: 341-378 and Part II 23: $385-424$.

[21] Sanders, B. H., 1933. Iron ores at Itabira Brazil. Inst of Min and Met Bull 396: 1-23.

[22] James, H. L., 1954. Sedimentary facies of iron formations. Econ Geol 49: 236-293.

[23] Klein, C., Beukes, N. J., 1992. Proterozoic iron formation. In: Kondie KC (ed.); Proterozoic crustal evolution, Amsterdam: Elsevier, p. 383-418.

[24] Ramanaidou, E., Nahon, D., Decarreau, A., Melfi, A. J., 1996. Hematite and goethite from duricrusts developed by lateritic chemical weathering of Precambrian banded iron formations, Minas Gerais, Brazil. Clays and Clay Minerals 44: 22-31.

[25] Ngaha, P. R. N., 1984. Contribution à l'étude géologique, stratigraphique et structurale de la bordure du bassin Atlantique du Cameroun. Thèse Doct. 3ème Cycle, Univ. de Yaoundé, 131p.

[26] Besnus, Y., 1977. Etude géochimique comparative de quelques gisements supergènes de fer. Thèse Université Louis Pasteur de Strasbourg (France), $101 \mathrm{p}$.

[27] Jacobson, R. L., Usdowski, E., 1975. Geochemical controls on a calcite precipitatingspring. Contrib. Mineral. Petrol., 51: 65.

[28] El Hadj, H., 2002. Les minéralisations aurifères dans les formations ferrifères d'Aouéouat, Tasiast, Mauritanie. Mémoire de Maîtrise, 229 p. Université du Québec à Montréal (UCAM).

[29] Canuto, V. M., J. S. Levine, T. R. Augustsson, C. L. Imhoff, and M. S. Giampapa, 1983: The young Sun and the atmosphere and photochemistry of the early Earth. Nature, 305, 281-286.

[30] Pickard, A. L., SHRIMP U-Pb Zircon Ages of Tuffaceous mudrocks in the Brockman Iron Formation of Hamersley Range, Western Australia. Australian Journal of Earth Sciences, Vol. 49, No. 3, pp. 491-507.

[31] Zeev, L., 2011. Banded Iron Formations (BIFs) and Associated Sediments Do Not Reflect the Physical and Chemical Properties of Early Precambrian Seas: International Journal of Geosciences, 2012, 3, 226-236

[32] Kasting, J. F., 1993. Earth's early atmosphere, Science. 259, 920-926. 